\title{
Introduction
}

\section{The Study of Cultural Encounters in Tharangampadi/Tranquebar}

Fihl, Esther; Puri, Stine Simonsen

Published in:

Review of Development and Change

Publication date:

2009

Citation for published version (APA):

Fihl, E., \& Puri, S. S. (2009). Introduction: The Study of Cultural Encounters in Tharangampadi/Tranquebar.

Review of Development and Change, XIV(1\&2), 7-19. 


\section{Introduction : The study of cultural encounters in Tharangampadi/Tranquebar

\author{
Esther Fihl \\ Stine Simonsen Puri
}

The present volume of Review of Development and Change takes the reader to the small coastal village of Tharangampadi, literally 'the village lashed by the waves' and known as Tranquebar in European discourse. Located in the Nagapattinam district of Tamilnadu, its unique history as a former Danish trading post, site of foundation of the first Lutheran church in India and the cradle of the Indian print history makes this village a privileged setting for the study of cultural encounters. In the past Tranquebar was the locus of interesting encounters related to colonial politics as well as missionary activity; today the area is integrated in a wider global context especially due to the export of fish, migration of labour, tourism and not least the presence of international NGOs in the aftermath of the tsunami in December 2004.

Both names - Tharangampadi and Tranquebar - are today in use locally and they reflect the long history of the place. This volume will employ both: Tharangampadi when working with a local Tamil perspective, and Tranquebar where the focus is on Tamil church traditions or on colonial or post-colonial relations. In this introduction we will use the name Tranquebar, since internationally this name is more widely known, as it is associated with the rich historical sources archived mainly in India, Denmark, Norway, England and Germany. ${ }^{1}$

Today, Tranquebar is a village of less than 10,000 inhabitants and about half the population is employed in fishing. With its impressive city gate, the

1 From an inscription dating from $1305 \mathrm{AD}$ on the local Hindu temple, Masilamaninathar, one more name of the village is known, Sandankanpadi. The inscription relates to sailors and a guild of 'traders of eighteen countries' (Subramanian 2003 p. 2f; Nagaswamy, n.d.), see also www.tharangampadi.dk. 
former Danish Fort on the seashore and linear streets with Lutheran churches, it has recently been designated a heritage town in India. An obvious cultural encounter takes place in the definition of the history of Tranquebar; thereby also of the modern use of buildings and the control over life and land. In addition there are encounters at the level of cultural and religious practices in the village today as well as back in history.

From the vantage point of different disciplines-history, social anthropology, religious studies, literary studies and the history of ideasthis relatively small geographical place of Tranquebar will be examined to let it grow in depth, revealing the multi-layered processes of change related to cultural encounters.

\section{Tranquebar: Past and Present}

Tranquebar is situated on the Coromandel coast which derives from the Tamil term Cholamandalam, 'realm of the Cholas', known to have been the rulers of most of South India between the ninth and twelvth centuries. Since the early fourteenth century, at the time of the Pandyan Kingdom, it has also been known for its Siva temple, Masilamaninathar, which bears inscriptions referring to the place as a trading port with merchants and soldiers stationed for their protection. During the Vijayanagara Empire (1336-1646), the place, with its location close to Tanjore (Thanjavur), was part of the Tanjore Province, which in 1535 was granted independence with the rule of the Nayaks lasting until 1673 (Subramanian 2003 p. 2ff).

The colonial history of Tranquebar begins in 1620 with the arrival of the Danish envoy Ove Giedde on the Coromandel coast as the head of the first Danish trading expedition, with the hope of signing a contract between the Danish King Christian IV and the King of Tanjore, Nayak Ragunatha. After some months of negotiations, the Danes were allotted Tranquebar and along with the already present Portuguese given a monopoly on all Tanjore's trade with Europe, (Fihl in this volume).

Assisted by the Dutch merchant Roland Crappe, who became the first Danish governor of the trading station in Tranquebar, Giedde founded Fort Dansborg, which served as the residence for the governor and other officials (Hjelm 1987; Subramanian 2003). From here silver, lead and guns were exchanged for Indian textiles and pepper. For the Danes, Tranquebar was a military stronghold and it functioned as a warehouse for commodities acquired also at other Indian localities and at places in Southeast Asia. In 1845, the trading post was sold to the British (Feldbæk 1969; Fihl 2008).

For the use of Tranquebar as a trading post, the Danes paid a yearly tribute to the Tanjore king thereby becoming part of a complex political system in South India based on reciprocal exchange of gifts and tributes between 
princely states (Fihl 1984). By the early nineteenth century, between 1808 and 1815, however, Tranquebar was occupied by the British military as a consequence of the wars in Europe. This complicated the payment of the tribute, which was of great symbolic and political importance for the Maratha King of Tanjore at that time, Rajah Serfoji II. Whereas the British saw the payment purely as an economic transaction, for the king of Tanjore, it was a matter of prestige and a symbol of his power (Rastén in this volume).

During the reign of Ragunatha (1612-1634) and in the following centuries, Tanjore court was a centre for performing arts, and it patronized the devadasis, female dancers serving at temples not only in Tanjore, but also in larger towns such as Tiruvarur, forty kilometres south-west of Tranquebar, where an important devadasi temple was located and from where dance steps as well as dancers were exchanged with the Tanjore court (Kersenboom-story 1987). There were devadasis in Tranquebar as well. In 1623, an Icelander Jon Olafsson, serving the Danish king in Tranquebar for a year as a soldier, observed temple dancers during processions outside the Masilamaninathar temple opposite Fort Dansborg, where he was on guard. Olafsson's notes of recollection are a unique historical source on the dance, which after Indian independence has been declared one of the national classical dances and through which today young women of various backgrounds, encounter the dance of the devadasis as a method of crosscultural understanding (Puri in this volume).

The first protestant church was founded in India in 1706, and happened to be located in Tranquebar. The Danish King Frederik IV had in that year sent two German missionaries from Halle, Bartholomæus Ziegenbalg and Heinrich Plütschau to Tranquebar in order to establish a Lutheran mission among his Indian subjects (Gross, Kumaradoss and Liebau 2006). The missionaries soon found themselves to be in deep conflict with the Danish officials and traders sent by the Danish trading company and who besides trading activities did not invest much time in taking part in the daily lives of the local Indians (Nørgaard 1987). The Danish-Halle mission, however, put much emphasis on social work and cultural understanding (Fihl 1988, Jeyaraj 1996).

Some years after their arrival in Tranquebar, the Lutheran missionaries set up a print station. At this print station, the first full translation of the Bible in Tamil was printed, which was the first translation of the Bible in any Indian language. The first Tamil grammar and dictionary books were also issued by the Danish press, which constitute a landmark for both future Tamil literacy and modern European understanding of Indian cultures (Venkatachalapathy 2003). For the early missionaries, the printing press became a new way of approaching the Tamil people of not only Tranquebar 
but also from much further beyond (Venkatachalapathy in this volume).

After the establishment of the Lutheran church, many different Christian protestant churches followed and spread out all over Tamilnadu (Bugge 1994). There was fierce competition among the various Christian denominations, and by 1845 , when the Danish trading post was sold to Great Britain, the congregations had mostly been taken over by the Anglican Church. In this context, the newly formed German Lutheran Leipzig Missionary Society made an effort to proselyte among the Anglican Christians as well as among the Roman Catholics in the Madras Presidency, with a more accommodating attitude towards the caste traditions. Thus, the Anglican and the Lutheran church tried to gain influence among the local population by adopting different strategies. One was to accept the caste system, the other was to reject it, and in doing so, both sought legitimacy by referring to the praxis of the first missionary in Tranquebar, Bartholomæus Ziegenbalg (Schönbeck in this volume).

During this time another Christian mission - The Danish Missionary Society - also rooted in the Danish-Halle mission, found its way to South Arcot district, a little north of Tranquebar. As social workers and educators, the missionaries mainly dealt with families in economic and social distress. In interfering with parenting issues however, the missionaries did not challenge the patriarchy of the Indian fathers, as children were of great importance to the missionary project (Vallgårda in this volume).

For Ziegenbalg as well as the later missionaries, establishing a school system became a key to a dialogue with the Hindu and Muslim communities. Even today, Tranquebar and its surrounding areas have a strong educational tradition, which is associated with the work of the different missions, and with the Tamil Evangelical Lutheran Church dominating the scene today (Grinder-Hansen in this volume).

Around the time of Indian Independence, a Danish school teacher Sophie Petersen wrote on Tranquebar on her return from a short visit. Aimed at a broad Danish audience she wrote in a romantic manner on the beauty of Tranquebar while stressing the ethical standards of its people. Simultaneously, she presented the loss of Tranquebar and other former Danish colonies in India, Ghana and West India as part of the high ethical and moral standards of the Danes. Through this representation, she was thus indirectly legitimizing Denmark's remaining colony, namely Greenland, a Danish colony as late as 1979 (Thisted in this volume).

In Tranquebar today, the memory of its Danish colonial past (16201845), even if it brings to light the injustice towards the locals, is not particularly apparent in the collective consciousness of its inhabitants. The memory of this past seems mixed or closely interlinked with the colonial experiences 
during the British reign which followed it. Therefore when trying to evoke or re-establish a memory of an Indo-Danish common history, one is confronted with the perception of the British rule in India. Local villagers encounter the past through a memory emphasizing certain events and leaving out others; here the myth of Ziegenbalg has a role to play in the construction of a past (Nonbo Andersen in this volume).

The southern part of the village is framed by the remains and contours of a former city wall from the seventeenth century built as part of the Danish trading post. Within the city walls are streets with Danish names, the Fort Dansborg, churches with Danish gravestones, and kids selling Danish coins to tourists - Indian as well as Danish, and other Europeans (Kryger \& Gasparski 2003; Hansen 2005). As this particular part of the village has been designated a heritage town by the Indian authorities, historical buildings are under renovation, some in cooperation between Indian and Danish institutions and NGOs. Yet, there are differing interests at play in the renovation work, related to ideas of social development and aesthetic ideals. It illustrates that the past is a contested space, which is brought to the present through the battle between different interest groups over the definition of the past of certain constructions (Jørgensen in this volume).

In December 2004, the tsunami struck Tranquebar. Close to 600 people died, mainly from the community of sea fishermen, who call themselves Chettiar fishermen (officially registered as Meenavar Pattinavar), and who live in the northern part of the village. As many fishing villages were destroyed along the southern Coromandel in the tsunami, the Tamilnadu state subsequently passed laws that banned re-building of housing close to the shore. Consequently, approximately 2,500 fishermen dwellings in Tranquebar have been moved inland to newly built relocation houses at the margins of the village. This has however hampered the traditional use of the beach as a working area for drying fish and entails an anxiety among the fishermen concerning the future use of the same space due to the recent establishment of hotels and the arrival of an increasing number of Indian and foreign tourists (Swamy in this volume).

Also other kinds of markers of geographical boundaries of life and land occur as Hindu, Christian and Muslim religious processions take place in the streets of the village. These religious processions emanate from the high number of churches as well as several Hindu temples and a mosque within Tranquebar. From these different places of worship in and around Tranquebar, several religious processions are held, where the gods and holy objects are taken out of their place of worship to be exposed to people and to pay visits to neighbouring places of worship. As such, these religious processions have an integrating function among people of different faiths and they reflect the pluralism of religions. Of the total population of Tranquebar, approximately 
85 per cent are Hindu, 8 per cent Christian and 7 per cent Muslim (Andersen in this volume).

In today's Tranquebar, the inhabitants belong to approximately twentyfive different jati (caste) communities. On the periphery of the village, resides a large community involved in different kinds of manual jobs, and who by other caste groups is designated by the derogatory term Parayiar (scheduled caste). Among them a single family of vettiyans employed as graveyard attendants and funeral drummers still resides, despised and avoided by everyone both outside and inside the community. The gradual disappearance of the vettiyan profession illustrates changes in the social, economic and symbolic status of low castes in Tranquebar. As the feudal organisation of labour has been replaced by capitalist market forces, and as the traditional system of tholil - work imposed as duty on the low caste communities has been prohibited by the Indian state, new opportunities for the vettiyans have come forth. However, one vettiyan remains indirectly forced to do the duties of his caste, but is determined to become the last vettiyan in Tranquebar (Lillelund in this volume).

\section{On the concept of cultural encounter}

The encounters which are dealt with in this volume exist on several levels: political, religious, aesthetic, economic and material, to name the most obvious. The distinctions are not clear though, as they overlap and spill over. Yet in each of the encounters, there is an important element of something 'cultural' and therefore we term it cultural encounters. In the following theoretical consideration, we argue that at a conceptual level, culture will always entail cultural encounters.

With the recent anthropological conceptualizations of culture, it is not to be understood as an essential entity or as an island in an ocean with other islands, each with an assemblage of inhabitants sharing homogenous worldviews and social habits. Rather, culture is always seen from a certain social position and thus worldviews and habits within a cultural group are never similar, but rather negotiated (Marcus \& Fischer 1999). The implications of this are twofold. On the one hand, culture does not exist without people, as it is people in specific social positions and situations who by their very dispositions and aspirations make culture, by explicitly or implicitly framing culture. In this social negotiation of culture, power is involved (Bourdieu 1977). On the other hand, cultures exist in relationship with other cultures through which people mirror themselves and construct cultural borderlines. People will draw borders of cultures from perceived differences and similarities in social habits and worldviews which in this process will be highlighted as special to them or attributed to others. Culture can thus be studied as a mental construct. Yet it is also a well of embodied social 
experiences and historical memories which has significance for the experience of one's own culture and history as well as those of others (Barth 1969 \& 1987; Hastrup 1992). Therefore culture in itself implies encounters, and cultures at an abstract level are also comparative, as they are defined in relation with other cultures.

A single person will most often not feel a part of just one culture, but of several cultures depending on contexts. Some of the actors described in the articles in this volume can be said to be in part a European, Danish, Christian or an occupational culture on the one hand, or an Indian, Tamil, Hindu, caste or royal culture on the other. Which one of the above perspectives on culture will be activated depends on the actual social situation in which he or she will draw cultural borders in relation with others.

Thus the starting point for the academic study of cultural encounters in this volume is to a great extent made up of events rather than of cultures as such, and the perspective on culture depends on the analytical context and time scale defined by the researcher. When cultural encounters are studied on the basis of events, the cultural significance in the encounters can be grasped and framed, without necessarily being simplified as a clash between predefined cultures. Cultural encounters can be studied by depicting the practical social situations in which agents with completely different agendas and visions will practice or work together in what can be designated an alternative space to negotiate the significance of their own cultural backgrounds and often find ways to interact despite differences (Fihl 2002; Tsing 2005).

At these events, agents with different cultural backgrounds meet, clash, and grapple with one another. This space might also be designated as a 'contact zone' and invokes the spatial and temporal co-presence of persons, ideas, traditions and things previously separated by geographical, mental or historical disjuncture and whose trajectories now intersect (Pratt 1992).

Recent studies on cultural encounters in an Indian context have to some extent been dominated by post-colonial theory. These often draw on the work of Edward Said. In his influential book Orientalism, Said argues that in the west, a Eurocentric image of Asian and Middle Eastern cultures has been constructed as an exotic 'other' which legitimized the political domination of the area. Therefore, working from a post-colonial perspective one tries to examine, on the one hand, how the cultural otherness of the colonized is constructed in such a way that they are made inferior to the colonizers, and on the other hand, the attempt of the colonized to reclaim their identity and worth is also examined. Ronald Inden (1990) and Nicholas Dirks (2001) have framed a post-colonial perspective that critically examines the impact of the British perspective on India and Indians as well as on the 
non-Indian's understandings of India besides the Indians' own selfunderstanding and view on their culture and society. Post-colonial studies in India have focused on the impact of the British during the eighteenth and nineteenth century. However, as this present volume will illustrate, cultural encounters in India have a much longer and more diverse history and also take place in modern life today.

That said, cultural encounters between Indians and outsiders did not start with the coming of the Europeans. Over the millennia, the Indian subcontinent has encountered various cultures through invasions and diffusions. Three centuries of Mughal rule - which however did not reach Tranquebarthe immediate predecessor of the British, for instance, had a profound impact on administrative structures, art and architecture, to name only a few of the more fruitful encounters. The co-existence of Hindu, Muslim and Christian groups of Tranquebar today is a result of former cultural encounters with Arab traders as well as impulses relating to the medeival Chola colonization of South East Asia and finally later encounters with the Christian missionaries from primarily Germany and Denmark. At some levels, the overall history of India is one of cultural encounters, between various cultural groups as India by itself is extremely heterogeneous.

M.N. Srinivas, the Indian social anthropologist/sociologist, has dealt with both the cultural encounters related to the Mughal Empire, the British Colony as well as the caste system. He is probably most known for his concept of Sanskritization, which describes the process of imitation of the practices and value system of the Brahmins and other powerful castes, through which people of less influential castes have aspired for an upward mobilization (Srinivas 1972). In these cultural encounters, the boundaries become blurred, and consequently it is difficult to pin point who is the 'other'.

Elizabeth Hallam and Brian V. Street (2000) provide a critical reflection upon academic discourses, which define and exaggerate the 'other' in studies of cultural encounters. Ann Laura Stoler (2002) has argued that the binary opposition between colonizer and colonized, which post-colonial theory is often based upon, can be very problematic. As we go deeper into the details of cultural encounters of Tranquebar past and present in this volume, it will become obvious that the 'other' is never simply given, never just found or encountered, but made and constructed in a process involving both power and negotiation (Fabian 1991). Recent writings on the cultural history of India have also shown the wealth of insight gained through detailed and grained studies of everyday phenomena (Venkatachalapathy 2006). This again points to the importance of examining the social, cultural and political institutions, events and processes where actual cultural encounters take place. These can be read as condensed situations where cultural otherness has been constructed in terms of race, caste and gender. Thus studies of cultural 
encounters can move beyond traditional conceptions of the 'west' and 'India' towards multi-directional and polyphonic angles taking into consideration the perspective of representatives from the communities, which take part in the encounters. Regardless of how difficult intercultural translations this might involve, the goal is to be faithful to the cultural representations on both sides (Sperber 1996).

The various theoretical sketches above offer frameworks to understand the impact of cultural encounters from a perspective that goes beyond fixed cultural categories. The assumption is that from the cultural encounters, persons move beyond their ascribed identity. This is not to say that one mixes one's identity with the identity of those one interacts with. Rather, a 'mutation', which is something in its own right, might evolve from the encounters (Arce \& Long 2000). In other words, cultural encounters are not just a mix between social and cultural forms, but they can create new forms, and therefore they are closely tied with questions of development and social change.

\section{On the study of one place}

This volume contributes varied examples of cultural encounters in one particular geographical place in India: Tranquebar. The examples come both from the past and from the present. They highlight events from the early seventeenth century, through the eighteenth and nineteenth century, till today's cultural encounters in the village.

As a whole, the present volume is an example of inter-disciplinary research on cultural encounters as well as social and cultural change at a single location through time. Together, the articles provide a basis for comparison of the implications of cultural encounters at different levels; the social, religious, material, economic, aesthetic, political, etc., and at different times. The volume therefore contributes to the general discussion on the methodology and theory of the study of cultural encounters and intercultural exchange.

As Tranquebar is not and never has been a closed community, the articles extend outside the borders of the village and also describe cultural encounters at a regional, national and even an international level. Yet the starting point is a demarcated geographical place, Tranquebar. When examining a place rather than a community, a culture, or a theme, the space opens up for a study of cultural encounters from various perspectives. As we find during colonial times, encounters took place between Danish officials and missionaries on the one hand and various representatives of Tamil society, such as dancers, parents and princes, on the other. The collection of articles illustrates different kinds of cultural encounters related to various events, institutions and situations and thus different spheres of cultural and 
social life.

The cultural encounters of today's Tranquebar sheds light on the heterogeneity of the village, as the encounters are not so much a matter of outsiders versus locals, as they take place within communities based on religion, class and caste. In this setting, outsiders are just as much Indian politicians or NGOs as they are Europeans and Danes - all with interests in Tranquebar's development after the tsunami and the classification of Tranquebar as a heritage town. Therefore the cultural encounters of today are not analysed mainly as encounters between 'the Indians' and 'the Europeans', but rather between groups of Indians divided along the lines of religion, caste and class, and thus the study of cultural encounters in Tranquebar is also a study of encounters among different groups of 'locals'.

Whereas the analyses of past Tranquebar are mainly based on letters, diaries, and reports from Danish officials and missionaries, the analyses of cultural encounters of today mainly rest upon interviews and participantobservation carried out during long-term ethnographic field work in the village. Some contributors combine the two, moving into the space between history and anthropology.

Rather than working from a single definition of cultural encounters, the articles reveal the scope of cultural encounters and its significance in development and social change. This may provide us with a framework from which methods that support sustainable development in Tranquebar as well as in other locations could develop, where cultural encounters are and have been a part of daily life.

The study of cultural encounters ideally takes into account the perspective of representatives from the groups which take part in the encounters. However, when dealing with past encounters, sources are not always available. Part of the post-colonial critique of the one-sided construction of the Indian other has to do with methodology. In Tranquebar, the local population has overall been illiterate, and therefore the sources on cultural encounters between Europeans or Danes and Indians are often limited to the Danish or British perspective, written in letters, diaries etc. and the Indian perspective can be teased out from these sources by reading against the grain. These 'indirect' Indian perspectives can mostly be traced to the more powerful social layer (kings of Tanjore), and those receiving a Christian education, or to Brahmins discussing with the early missionaries. This illustrates the fact that it is rather difficult to speak of an Indian or a Danish perspective as Indians and Danes, in the past or present, among themselves perceive their respective culture and history differently.

Even when the emphasis is on Tranquebar as a former Danish trading post, the cultural encounters go beyond the question of Indo-Danish 
relationships. People from places as diverse as Iceland, Germany, France and Great Britain have come to Tranquebar as soldiers, tradesmen, or missionaries. Yet, national identity is not always the most relevant difference established between the groups present in Tranquebar and it is important to note that 'cultural' in cultural encounters, does not per se refer to national cultures.

As a trading post, not only goods and money were being exchanged, but also ideas, values and customs. From this exchange, new things, forms, social structures, and ideas developed. That said, cultural encounters do not as such imply change in the direction of something new. First of all cultural encounters create an awareness, consciously or unconsciously, of oneself and what one is part of through a categorization of what is different from oneself. In this way the construction of culture, history and national identity are lucid in cultural encounters.

However, if instead of thinking of cultural encounters as a matter of separate groups existing at a historical time in opposition to one another, we let the investigations unfold as examinations of how these encounters crisscross over places, groups, spheres of life and time, we may get a more complex understanding of the unique forms and connections that grow from the encounters. These issues can be approached through a two-pronged methodology that combines descriptions of empirical data connected with particular historical junctures past or present on the one hand, and analytical reflections on how these data are shaped and informed by cultural encounters on the other. Together, the articles in this volume will show how a small village like Tranquebar is connected to places, people, religious ideas, things etc. through past and present cultural encounters.

\section{References}

Arce, Alberto \& Norman Long (2000), 'Reconfiguring Modernity from an Anthropological Perspective'; In Arce \& Long (eds.) Anthropology, Development and Modernities: Exploring Discourses, Counter Tendencies and Violence. London: Taylor and Francis.

Barth, Fredrik (1969), Ethnic Groups and Boundaries: The Social Organization of Cultural Differences, Oslo: Oslo Universitetsforlag.

Barth, Fredrik (1987), Cosmologies in the Making: A Generative Approach to Cultural Variation in Inner New Guinea, Cambridge: Cambridge University Press.

Bourdieu, Pierre (1977), Outline of a Theory of Practice, Cambridge: Cambridge University Press.

Bugge, Henriette (1994), Mission and Tamil Society. Nordic Institute of Asian Studies Monograph Series, No. 65, Wiltshire: Curzon Press.

Dirks, Nicholas B. (2001), Castes of Mind: Colonialism and the Making of Modern India, Princeton: Princeton University Press. 
Fabian, Johannes (1991), Time and the Work of Anthropolog,. Critical Essays 19711991. Chur: Harwood Academic Publisher.

Feldbæk, Ole (1969), India Trade under the Danish Flag 1772-1808. Scandinavian Institute of Asian Studies Monograph Series, No. 2. Odense: Studenterlitteratur.

Fihl, Esther (1984), 'Some Theoretical and Methodological Considerations on the Study of Danish Colonialism in Southeast India', In FOLK, The Danish Ethnographical Association, vol. 26. Copenhagen.

Fihl, Esther (1988), 'B. Ziegenbalgs“Malabarischen Heidenthums” Die Kulturanschaung des ersten Lutherischen Missionars in Ostindien', In Zeitschrift für Missionswissenschaft und Religionswissenschaft, 72 Jahrgang, Heft 3. Münster.

Fihl, Esther (2002), Exploring Central Asia: Collecting Objects and Writing Cultures from the Steppes to the High Pamirs 1896-1899, vols I-II. Copenhagen: Rhodos International Science and Art Publishers.

Fihl, Esther (2008), 'Tropical Colonies', In Prem Poodar, Rajeev Patke \& Lars Jensen (eds.) Postcolonial Literatures: Continental Europe and its Empires. Edinburgh: Edinburgh University Press.

Gross, Andreas, Y. Vincent Kumaradoss \& Heike Liebau, eds. (2006), Halle and the Beginning of Protestant Christianity in India. Vol. I-III. Halle: Verlag der Franckeschen Stiftungen zu Halle.

Hallam, Elizabeth \& Brian V. Street, eds. (2000), Cultural Encounters. Representing 'Otherness', London and New York: Routledge.

Hansen, Hans Munk (2005), Tranquebar: Town and Buildings of the Danes, Kunstakademiets Arkitektskole: Copenhagen.

Hastrup, Kirsten, ed. (1992), Other histories, London and New York: Routledge.

Hjelm, Torben (1987), 'Dansborg', in Arkitekturhistorisk Årsskrift. ARCHITECTURA, Tranquebar, vol. 9, p. 89-121. Copenhagen.

Inden, Ronald B. (1990), Imagining India, Oxford: Blackwell Publishing.

Jeyaraj, Daniel (1996), Inkulturation in Tranquebar: Der Beitrag der frühren dänishhalleschen Mission zum Werden einer indisch-einheimischen Kirche (1706-1730). Erlangen: Verlag der Ev.-Luth. Misssion Erlangen.

Kersenboom-Story, Saskia (1987), Nityasumangali. Devadasi Tradition in South India. Delhi: Motilal Banarsidass.

Kryger, Karin \& Lisbeth Gasparski (2003), Tranquebar:- Cemeteries and Grave Monuments, Copenhagen: Kunstakademiets Arkitektskole.

Marcus, George, E. \& Michael M. J. Fischer (1999), Anthropology as Cultural Critique: An Experimental Movement in the Human Sciences, Chicago and London: University of Chicago Press.

Nagaswamy, R (n.d.), Tarangampadi, Madras: B. S. Combine. 
Nørgaard, Anders (1987), Mission und Obrigkeit. Die Dänish-hallische Mission in Tranquebar 1706-1845. Missionswissenschaftliche Forshungen, Band 22. Gütersloh: Gütersloher Verlaghaus Gerd Mohn.

Pratt, Mary Louise Pratt (1992), Imperial Eyes: Travel Writing and Transculturation. London and New York: Routledge.

Said, Edward.(1979), Orientalism, New York: Vintage Books.

Sperber, Dan (1996), Explaining Culture: A Naturalistic Approach, Oxford \& Malden: Blackwell Publishers.

Srinivas, M.N. (1972), Social Change in Modern India, Delhi: Orient Longman.

Stoler, Ann Laura (2002), Carnal Knowledge and Imperial Power: Race and the Intimate in Colonial Rule, Berkeley: University of California Press.

Subramanian, T. (2003), Tarangampadi (Tranquebar): Excavation \& Conservation Report 2001-2002, edited by R. Kannan. Chennai: Department of Archaeology, Government of Tamilnadu.

Tsing, Anna Lowenhaupt (2005), Friction: An Ethnography of Global Connection, Princeton: Princeton University Press.

Venkatachalapathy, A.R. (2003), 'Tamil Literary Canon in the Colonial and Postcolonial Worlds'. In Suman Gupta, Tapan Basu, Subarno Chattarji, eds, India in the Age of Globalization: Contemporary Discourses and Texts, New Delhi: Nehru Memorial Museum and Library.

Venkatachalapathy, A.R. (2006), In those Days there was No Coffee: Writings in Cultural History, New Delhi: Yoda Press. 